\title{
Legal Regulation of Alcohol Sale in Retail Sectors of Hospitality Industry in Accra
}

\author{
Adelaide Grace Mensah-Kufuor \\ Hotel Catering \& Institutional Management Department, Accra Technical University, Accra, Ghana
}

Email address:

madelaidegrace@yahoo.com, amensahkufuor@apoly.edu.gh

\section{To cite this article:}

Adelaide Grace Mensah-Kufuor. Legal Regulation of Alcohol Sale in Retail Sectors of Hospitality Industry in Accra. Hospitality \& Tourism Management. Vol. 2, No. 1, 2018, pp. 1-7. doi: 10.11648/j.ijhtm.20180201.11

Received: May 15, 2017; Accepted: July 4, 2017; Published: April 17, 2018

\begin{abstract}
This research examines the legal regulations governing the sale of alcohol in retail sectors of the Hospitality Industry in Accra, Ghana. The objectives of the study were to find out whether there are laws governing the sale of alcohol in the retail sectors and to establish what these laws are. Determine which governmental body is responsible for the enforcement of the alcohol regulations and how well they execute their duties. Examine the knowledge level of operators observing alcohol laws and ascertain the necessary requirements for operators to acquire license to operate. Descriptive survey design was used to quantitatively and qualitatively collect the data from drinking bar operators and law regulators/law enforcement body respectively. The sample procedure employed was the cluster sample method. Statistical Package for the Social Sciences (SPSS) was used to analyse and process the data from the questionnaires and thematic analyses was used to qualitatively analyse the interview to augment the data from the questionnaire. Findings reveal that there are laws/regulations governing the sale of alcohol, regulated by the statutory boards, yet there is a big gap between the laws governing the sale of alcohol and what is being practiced /observed on the Ghanaian market. Majority of the alcohol sellers/operators did not know these laws and those who knew also find it very difficult to observe them. In conclusion, the knowledge and adherence of these laws is vital and beneficial to all, therefore the need to educate the citizenry. This study also offer suggestions to the regulators, that they should endeavour to reinstate these laws and help operators to obey them by educating, monitoring and administering punishment to those who do not abide by them.
\end{abstract}

Keywords: Hospitality, Industry, Alcohol, Sale, Regulations, Accra

\section{Introduction}

Hospitality is the act of kindness in welcoming and looking after the basic needs of customers or strangers, mainly in relation to food, drink and lodging. In effect, the Hospitality Industry refers to the firms or organizations which provide a place for sleeping, food and beverage, and other ancillary services to people who are "away from home" [2]. The hospitality industry is a multi-billion dollar industry which depends mostly on the availability of leisure time and disposable income. There are various sectors of the industry which includes the accommodation sector; this sector is responsible for providing people with suitable places to stay such as hotels, motels, resorts, hostels and service departments. Each of these establishments provides a different level of service from luxury to economy/selfservice. The Food and beverage sector is the fastest growing sector of the hospitality industry. This sector which provides people with arrange of meals and beverages include retail sectors such as restaurants, cafés, fast food outlets, bars, night clubs, pubs, spots and public houses. Like the accommodation sector, the food and beverage sector offers arrange of services and levels of quality [2].

In Ghana, a developing country for instance, there is a wide range of drinking bars, a business with the primary function of serving alcoholic beverages for consumption on the premises like spots, pubs and night clubs. These establishments which may be unlicensed or licensed to sell alcoholic drinks for consumption on the premises are scattered all over the country. These subsectors come under the umbrella of the retail sectors of the hospitality industry which provide allsorts of alcoholic and non-alcoholic beverages. The majority of these beverages are hard liquor which are sold to vast number of the population regard less of the age of the buyer or consumer, the time of the day or place. Alcohol may be the world's oldest known drugs, fermented grains; fruit juices and honey have been used to make alcohol which is ethyl alcohol or ethanol for thousands of years. 
Alcohol, an oxygenated hydrocarbon is both a food and a drug. It is a food because it gives energy when the body works on it even though more energy than what it gives is required to break down its waste. It is a drug because it affects the body chemically and the body breaks down [3]. The production of products containing alcohol has become huge, highly invested and a profitable business in today's society and its consumption and abuse has become a major social public health problem. The World Health Organization [4] has indicated that in developed countries, the harm from alcohol is ranked third out of 26 risk factors examined in terms of their contribution to diseases, disability or mortality [5]. In recent years, there are initiatives in place which promote alcohol, increase access to alcohol and stimulate alcohol sales.

The effects of alcohol abuse range from a mild hang over to mass destruction, disease and death on a larger scale. In recent years, there are initiatives in place which promote alcohol, increase access to alcohol and stimulate alcohol sales [5]. For example, in the United Kingdom (UK), the rise in the afford ability of alcohol by $65 \%$ between 1980 and 2006 , the extension of hours of sale for both on/off premises outlets in 2003, combined with extensive advertising and the promotion of alcohol have been linked with an increase in consumption and drinking related damages [6]. Alcohol is the third largest contributing factor to injury and disease world wide, almost equal to tobacco in developing countries with overall low mortality [7]. Factors which influence how alcohol will affect a person include age, gender, physical condition, other drugs or medicine taken.

The social responsibility function do not include controlling overall sales or reducing high-risk drinking, both of which have been linked with population-level rates of damage, caused by alcohol consumption [7]. The level of alcohol consumption has become a worry to the society, as it has virtually become the 'solution' to people's problems. Whenever some people face any challenge, they tend to abuse alcohol thinking it will help forget their problems. The majority of them are into alcohol abuse, for the health and social risk that are related to alcohol. Every alcoholic beverage has the propensity to produce innumerable health problems owing to its consumption including obsession, impotence, decline in social status, as well as massive health burdens imposed on the nation as a whole.

\subsection{Problem Statement}

There are regulations governing the sale and consumption of alcohol in Ghana. These alcohol regulations are: price/tax restrictions, age-based availability restrictions, spatial availability restrictions, and temporal availability restrictions; all these are controlled by the Liquor License Act 1987. For example, no holder of a "license to sell" liquor or alcohol shall supply or sell in toxic ting liquor to persons under the age of 18 years in a licensed premise. The sale of alcoholic beverages is controlled by the Liquor License Control Act which aims to control the sale and consumption of alcohol, to reduce them is use of alcohol and to promote improvements within facilities which serve alcohol. One would then wonder why the operators in some areas do not abide by the laws and regulations governing the sale of alcoholic beverages.

In the retail sectors of the hospitality industry of which the "Spots" are all included, alcohol is sold to any person who is in the premises and want to buy regardless of the age and the time of day. Alcohol is believed to bean appetizer in Ghana, consequently users drink it before a meal to enable the meat well. Even though moderate amount of alcohol may boost appetite in some people, excess of it decreases appetite. This has increased the level of alcohol consumption and or abuse and its tragic consequences in the society because there are no restrictions on who to sell to, when to sell and to what quantity one can consume. Very few individual so who consume alcohol do so without harmful outcomes.

Consumers drink alcohol because of their belief that it gives them pleasure; owing to its effects as a social lubricant, it is a marker of celebration around important life events and because of its ritualistic role in a number of religions [6]. Where as most of those who drink do so responsibly and moderately, them is use or irresponsible consumption of alcohol has the potential to impose harm on both individuals and society through arrange of health and social problems. Alcohol on the whole causes more harm than good and thus its consumption, especially in large quantities needs to be curtailed [3]. The question which needs to be asked is, 'Are there regulations, principles or codes of practices governing the sale of alcohol in our societies'. The legal regulations governing the sale of alcohol are not known or being enforced, therefore most people are in to the business of alcohol sale because it has become one of the lucrative businesses in Ghana. Legislation will be necessary to control the distribution and use of alcohol in the country; a national policy is therefore necessary. The legal regulations governing the sale of alcohol should and must be observed or made obligatory.

\subsection{Research Questions}

1. What governmental body is responsible for the enforcement of the alcohol regulations in Accra?

2. How effective is the body in executing their duties?

3. What is the knowledge level of the operators in observing alcohol regulations?

4. What are the necessary requirements for one to obtain a license to operate an alcoholic outlet?

\subsection{Study Objectives}

The main objective of this study is to find out whether there are laws governing the sale of alcohol in the retail sectors of the hospitality industry and to establish what these laws are.

The specific objectives are to:

1. Determine which governmental body is responsible for the enforcement of the alcohol regulations in Accra.

2. Examine how effective the law enforcers are in executing their duties.

3. Assess the knowledge level of operators in observing alcohol regulations.

4. Ascertain the necessary requirements for operators to obtain a license to operate an alcoholic outlet. 


\section{Alcohol Regulations}

The hospitality industry is covered by many Acts and regulations which relate to employers, employees and consumers. Regulations on the availability of alcohol have been used to moderate alcohol problems in communities throughout the world for over a thousand years. In the latter half of the $20^{\text {th }}$ century, qualitative and quantitative studies on the effects of these regulations on drinking and related problems began in earnest as public health practitioners began to recognize the full extent of the harmful consequences related to drinking [7]. States regulate many features of alcohol accessibility, from the age at which someone can purchase alcohol to the types of stores where alcohol can be sold as well as the setting and hours of operation of those stores. For instance, alcohol regulation is demonstrated by the Minimum Legal Drinking Age (MLDA) set by various governments of states. Individual states have established different minimum age sat which alcohol could be purchased from retail outlets. Some states have established the MLDA at age 18 , others at age 21 , some at age 18 for beer and age 21 for liquor, and so forth [11]. The minimum drinking age in Ghana is 18 (Section-15(1) of Ghana Liquor License Act 1970 (ACT 331). MLDA makes it more difficult for under-age drinkers to purchase alcohol, reduces drinking among under-age youth who grow up instates with higher MLDAs, and also reduce alcohol-related motor-vehicle accidents among other problems [11]. MLDA laws are effective, and comparatively easy to implement and enforce. Although under age youth still obtain alcohol through other means, MLDA laws are beneficial to the society and estimated to save 1,000 lives of young people each year [12].

In recent years, all jurisdictions have undergone considerable changes on how alcoholic beverages are distributed and sold [5]. The most not able changes include: an increase in alcohol marketing and promotion, increase in alcohol density within retail outlets, the extension of hours and days of sale, and the use of discounts on selling prices in order to promote sales. Provincial liquor boards and commissions include management of alcohol sales as part of their mandate. However, the current control functions are narrowly restricted to social responsibility initiatives, interventions to control smuggling, concerns about the quality of products, and some health promotion campaigns, such as prevention of drinking and driving. The social responsibility functions do not include controlling overall sales or reducing high-risk drinking, both of which have been linked with population-level rates of damage, caused by alcohol consumption [8].

\subsection{Regulations on the Tax/Price of Alcohol}

Economists studying the relationship between alcohol and crime have largely focused on alcohol control policies which change the full price of alcohol either directly (through alcohol excise taxes) or indirectly (through other non-price availability restrictions). A tax-induced upsurge in the price of alcohol should reduce alcohol consumption by the law of demand (Academics Association, now known as the Council on Community Economic Research, or C2ER). Taxes are more than fully shifted to prices using unique review data from before and after a large alcohol tax hike in Alaska.

Finally, a focus on alcohol taxes has substantial policy relevance as several states have debated and implemented significant increases in alcohol taxes in the past few years. Although some research have called the relationship between state beer taxes and alcohol consumption in to question, particularly for young adults [4], other recent researches have confirmed that tax-induced price increases for ethanol are associated with decreases in drinking [10].

Alcohol taxes in real terms have been falling steadily for decades, and economists commonly argue that alcohol taxes are too low [9]. Economic theory predicts that higher alcohol taxes should reduce both alcohol consumption and crime, to the extent that crime is caused by drinking. Yet the evidence on the effects of alcohol taxes has been limited by the fact that there have not been many significant changes in the rate at which alcohol is taxed.

\subsection{Positive Effects of Alcohol Consumption}

Although alcohol consumption is generally perceived to have diverse adverse effects, the following can be rightly laid out as positive effects or benefits of using alcohol:

1. Relieves mental stress: It is believed to give relief from mental tension after a day's activities; hence its consumption provides relief from stress.

2. Provides better sleep: Alcohol has a downer effect

3. Increases appetite: Alcohol raises blood flow to the stomach and gut and also as light irritant locally. This property rises hunger and there by food consumption.

4. Keeps body warm in winter and cold conditions; alcohol rises blood flow to the skin and there by produces warmth.

5. Alcohol is a good solvent for many extraction procedures including plant constituents, drugs.

\subsection{Negative Effects of Alcohol Consumption}

Alcohol enters blood stream as soon as is taken by first sip. Alcohol's immediate effects can appear within 10 minutes as drinking increases Blood Alcohol Concentration (BAC) level which is the amount of alcohol present in the blood stream. The higher the BAC, the more impaired one becomes. These effects can include: Reduced inhibitions, Slurred speech, Motor impairment, Confusion, Memory problems, Concentration problems, Coma, Breathing problems, and even Death. [8], Those who drink too much over along period of time may experience alcohol's longer-term effects, which can include: Alcohol reliance and Health problems augment peril for certain cancers. Drinking too much-on a single occasion or over time-can take a serious toll on one's health. Alcohol interferes with the brain's communication pathways, and can affect how the brain looks and works. These disruptions can change one's mood and behavior, and make it harder to think clearly or move with co-ordination.

\section{Methodology}

The study area is Accra, the capital land the largest city in Ghana, The city of Accra hosts these at of Government, 
diplomatic missions, most of the government ministries and agencies, and head office of most business and organizations. Accra is an industrial centre (area) where immigrants from other regions come to seek greener pastures, resulting in the area being very densely populated. Accra is a financial centre where a lot of trading activities goes on and artisans relax to drink after a hard day's work or 'relax' their nerves. Accra is a very lucrative area for the sale of alcohol.

\subsection{Population and Sample}

The research targeted a population of three law regulators, one from a law enforcement body and 50 operators of drinking bars or "Spots" from five densely populated areas in Accra. These areas are Korle Gonno, Chorkor, Jamestown, Lapaz, Abeka and Kaneshie.

\subsection{Sample Size}

The sample size consisted of one operator each from the 50 selected "Spots", three personnel from the law regulatory body and one personnel from the law enforcement body, totaling 54 respondents.

\subsection{Data Collection Instruments}

The instruments used to collect data for the research were self-administered questionnaires for the bar operators and an interview schedule for the law regulators and law enforcement body. Open and close-ended questions were used to obtain information, whilst an interview guide was used to interview the law regulators. The questionnaires were administered to the respondents (bar operators) personally and collected the same day. Conducive dates for the participants were fixed to conduct the interviews.

\section{Analysis of Data}

Table 1. Socio demographics of the law regulators.

\begin{tabular}{lll}
\hline Socio demographics' of law regulators & Frequency & Percentage \\
\hline Gender & 3 & \\
Male & 3 & 100.0 \\
Total & & 100.0 \\
Age & 1 & \\
$46-50$ & 2 & 33.3 \\
Above 60 & 3 & 66.7 \\
Total & & 100.0 \\
Level of education & 1 & \\
Polytechnic/University & 2 & 33.3 \\
Postgraduate & 3 & 66.7 \\
Total & & 100.0 \\
Years in operation & 1 & \\
6-10 & 1 & 33.3 \\
16-20 & 1 & 33.3 \\
Above 21 & 3 & 33.3 \\
Total & & 100.0 \\
Marital status & 3 & \\
Married & & 100.0 \\
\hline
\end{tabular}

Source: Field survey, 2015

The Respondent from this section are male within the ages of 46-60, are post graduate holders who have been in operation for 6-21years and are all married.
Table 2. Regulators.

\begin{tabular}{|c|c|c|c|}
\hline & & Frequency & Percentage \\
\hline 1 & $\begin{array}{l}\text { Are there legal regulations governing } \\
\text { the sale of alcohol? }\end{array}$ & & \\
\hline & Yes & 3 & 100.0 \\
\hline & Total & 3 & 100.0 \\
\hline 2 & $\begin{array}{l}\text { Do you train operators before issuing } \\
\text { license? }\end{array}$ & & \\
\hline & Yes & 1 & 33.3 \\
\hline & No & 2 & 66.7 \\
\hline 3 & $\begin{array}{l}\text { Total } \\
\text { Are operators monitored to ensure } \\
\text { the compliance of the law? }\end{array}$ & 3 & 100.0 \\
\hline & Yes & 3 & 100.0 \\
\hline 4 & $\begin{array}{l}\text { Total } \\
\text { Can an already obtained license be } \\
\text { withdrawn? }\end{array}$ & 3 & 100.0 \\
\hline & Yes & 3 & 100.0 \\
\hline 5 & $\begin{array}{l}\text { Total } \\
\text { Does the law react to excessive } \\
\text { alcohol advert? }\end{array}$ & 3 & 100.0 \\
\hline & Yes & 2 & 66.7 \\
\hline & No & 1 & 33.3 \\
\hline & Total & 3 & 100.0 \\
\hline
\end{tabular}

Source: Field survey, 2015

Table 2; shows that majority of the respondents responded yes to the questions asked. This indicates that there are regulations governing the sale of alcohol in Accra.

Table 3. Socio-demographic of alcohol outlet operators.

\begin{tabular}{|c|c|c|}
\hline Socio-demographics of operators & Frequency & Percentage \\
\hline \multicolumn{3}{|l|}{ Gender } \\
\hline Male & 31 & 62.0 \\
\hline Female & 19 & 38.0 \\
\hline Total & 50 & 100.0 \\
\hline \multicolumn{3}{|l|}{ Age } \\
\hline $25-29$ & 15 & 30.0 \\
\hline $30-35$ & 23 & 46.0 \\
\hline $36-40$ & 6 & 12.0 \\
\hline $41-45$ & 3 & 6.0 \\
\hline $46-50$ & 1 & 2.0 \\
\hline Above 50 & 2 & 4.0 \\
\hline Total & 50 & 100.0 \\
\hline \multicolumn{3}{|l|}{ Highest educational level } \\
\hline Primary & 23 & 46.0 \\
\hline Secondary & 21 & 42.0 \\
\hline Vocational & 5 & 10.0 \\
\hline Polytechnic/University & 1 & 2.0 \\
\hline Postgraduate & 0 & 0.0 \\
\hline Total & 50 & 100.0 \\
\hline \multicolumn{3}{|l|}{ Number of years in operation } \\
\hline $2-5$ & 17 & 34.0 \\
\hline $6-10$ & 25 & 50.0 \\
\hline $11-15$ & 3 & 6.0 \\
\hline $16-20$ & 3 & 6.0 \\
\hline Above 20 & 2 & 4.0 \\
\hline Total & 50 & 100.0 \\
\hline \multicolumn{3}{|l|}{ Marital status } \\
\hline Single & 33 & 66.0 \\
\hline Married & 13 & 26.0 \\
\hline Divorced & 3 & 6.0 \\
\hline Widow/Widower & 1 & 2.0 \\
\hline Total & 50 & 100.0 \\
\hline
\end{tabular}

Source: Field Survey, 2015

Interpretation of table 3

Table 3; represents the socio demographics of the operating respondents. There are 50 respondents in all, out of 
the 50,31 are male which represented $62 \%$ of the population and female, $38 \%$. Fifteen of them which represent $30 \%$ are between the ages of $25-29,46 \%$ of the respondents are between 30-35 years, 6 of them in their late $30 \mathrm{~s}, 6 \%$ of the respondents are between the ages of $41-45$ and $6 \%$ in the ages ranging from 46 and above.

The highest educational level of the respondents ranged from Primary to Tertiary. $46 \%$ of them are primary school leavers, $42 \%$ are from secondary school, $10 \%$ of the respondents attended vocational schools, and only one of them $(2 \%)$ had attained Tertiary qualification. This shows that majority of the respondents are primary school leavers.

According to Table 3, $50 \%$ of the operators have been in operation for 6 to 10 years, $34 \%$ are in existence for 2 to 5 years. Three of the respondents which are $6 \%$ have operated for 11 to 15 years, another $6 \%$ have operated for 16 to 20 years and only $4 \%$ of them have been in operation for more than 20 years. Averagely, alcohol outlet operators have been in existence for 6-10 years.

The marital status of the respondents shows that $66 \%$ of them are single, $26 \%$ are married, $6 \%$ are divorced, with only $2 \%$ which is one person, being a widow. This portrays most of the respondents being single.

Table 4. Statements about alcohol operation.

\begin{tabular}{llll}
\hline No & Statements & Frequency & Percentage \\
\hline 1 & Type of outlet & & \\
& Spot & 25 & 50.0 \\
& Pub & 14 & 28.0 \\
& Nightclub & 11 & 22.0 \\
& Total & 50 & 100.0 \\
2 & Seating capacity & & \\
& 25-50 & 15 & 30.0 \\
& 51-75 & 25 & 50.0 \\
& 76-100 & 5 & 10.0 \\
& Above100 & 5 & 10.0 \\
& Total & 50 & 100.0 \\
& Trading hours & & \\
& 4am-11pm & 17 & 34.0 \\
\hline
\end{tabular}

\begin{tabular}{llll}
\hline No & Statements & Frequency & Percentage \\
\hline & 6am-12midnight & 30 & 60.0 \\
& $24 / 7$ & 3 & 6.0 \\
& Total & 50 & 100.0 \\
4 & Working days & 3 & \\
& Weekdays & 5 & 6.0 \\
& Weekends & 2 & 10.0 \\
& Once a week & 40 & 4.0 \\
& 24/7 & 80.0 \\
& Total & 50 & 100.0 \\
\hline
\end{tabular}

Source: Field survey, 2015

Table 4; talks about the alcohol outlets, Most of the operators operate a drinking Spot with a sitting capacity of 51-75; they operate everyday from 6 am to 12 midnight. The types of beverages sold are both alcoholic and non-alcoholic beverages which are sold to laborers or workers. Majority of the customers who patronize these places are above 18 years and just $6 \%$ of the respondent do not have a license to operate.

Table 5. Statements about alcohol operation

\begin{tabular}{llll}
\hline $1 \quad$ Types of beverage & & \\
& Alcoholic & 7 & 14.0 \\
Non-alcoholic & 4 & 8.0 \\
Both & 39 & 78.0 \\
& Total & 50 & 100.0 \\
$2 \quad$ Do you have a License to operate? & & \\
Yes & 47 & 94.0 \\
No & 3 & 6.0 \\
Total & 50 & 100.0 \\
\hline
\end{tabular}

Source: Field survey, 2015

The beverages sold here are both alcoholic and nonalcoholic with majority being alcoholic. Only $6 \%$ do not have a license to operate as an alcoholic outlet.

SECTIONB: Knowledge Test. Liquor License Act 1970, (Act 331)

Table 6. Liquor license knowledge test.

\begin{tabular}{|c|c|c|c|}
\hline No & Statements & Frequency & Percentages \\
\hline 1 & $\begin{array}{l}\text { No holder of a license to sell spirits, wine or beer shall allow any person under the apparent age of } 18 \text { years to beat } \\
\text { anytime in the bar of the licensed premises during permitted hours. }\end{array}$ & & \\
\hline \multirow{7}{*}{2} & Yes & 40 & 80.0 \\
\hline & No & 10 & 20.0 \\
\hline & Total & 50 & 100.0 \\
\hline & $\begin{array}{l}\text { If a person under the apparent age of } 18 \text { years is found in the bar of any licensed premises during permitted hours, } \\
\text { the holder of the license shall be deemed to have committed an offence. }\end{array}$ & & \\
\hline & Yes & 42 & 84.0 \\
\hline & No & 8 & 16.0 \\
\hline & Total & 50 & 100.0 \\
\hline 3 & $\begin{array}{l}\text { Any licensee who contravenes this section, and any person who causes or procures any person under the apparent } \\
\text { age of } 18 \text { years to enter or to be in the bar of any licensed premises during the permitted hours, shall be guilty of an } \\
\text { offence and liable on conviction to affine and in default of payment to imprisonment. }\end{array}$ & & \\
\hline \multirow{7}{*}{4} & Yes & 35 & 70.0 \\
\hline & No & 15 & 30.0 \\
\hline & Total & 50 & 100.0 \\
\hline & $\begin{array}{l}\text { No licensee shall sell any spirit, wine or beer to any drunken person or permit any disorderly or improper conduct on } \\
\text { his premises or any part of the premises. }\end{array}$ & & \\
\hline & Yes & 32 & 64.0 \\
\hline & No & 18 & 36.0 \\
\hline & Total & 50 & 100.0 \\
\hline 5 & $\begin{array}{l}\text { Any police officer in uniform may demand the name and address of any person found after the permitted hours on } \\
\text { any premises licensed for the sale of spirits, wine or beer, and if he has reasonable ground to suspect that the name or }\end{array}$ & & \\
\hline
\end{tabular}




\begin{tabular}{|c|c|c|c|}
\hline No & Statements & Frequency & Percentages \\
\hline & address given is false, he may require evidence of its correctness. & & \\
\hline & Yes & 28 & 56.0 \\
\hline & No & 22 & 44.0 \\
\hline & Total & 50 & 100.0 \\
\hline \multirow[t]{4}{*}{6} & $\begin{array}{l}\text { Any person who fails upon demand to give his name and address, or satisfactory evidence of such name and address, } \\
\text { may be arrested by the police officer without warrant and taken as soon as practicable before a magistrate. }\end{array}$ & & \\
\hline & Yes & 26 & 52.0 \\
\hline & No & 24 & 48.0 \\
\hline & Total & 50 & 100.0 \\
\hline \multirow[t]{4}{*}{7} & No licensee under the Act shall sell 'akpeteshie', spirits, beer or wine to any police officer in uniform. & & \\
\hline & Yes & 19 & 38.0 \\
\hline & No & 31 & 62.0 \\
\hline & Total & & 100.0 \\
\hline \multirow[t]{4}{*}{11} & Do you know who a minor is? & & \\
\hline & Yes & 34 & 68.0 \\
\hline & No & 16 & 32.0 \\
\hline & Total & 50 & 100.0 \\
\hline \multirow[t]{4}{*}{12} & Is it an offence to sell hard liquors to a minor? & & \\
\hline & Yes & 32 & 64.0 \\
\hline & No & 18 & 36.0 \\
\hline & Total & 50 & 100.0 \\
\hline \multirow[t]{4}{*}{13} & Is it legal to trade from $11 \mathrm{pm}-4 \mathrm{am}$ ? & & \\
\hline & Yes & 12 & 24.0 \\
\hline & No & 38 & 46.0 \\
\hline & Total & 50 & 100.0 \\
\hline
\end{tabular}

Source: Field survey, 2010

No person shall sell wine or beer on any premises or in the open, except under and in accordance with one of the following:

Table 7. Liquor license knowledge test.

\begin{tabular}{|c|c|c|c|}
\hline No & Statements & Frequency & Percentage \\
\hline \multirow[t]{4}{*}{15} & A spirit license granted & & \\
\hline & Yes & 33 & 66.0 \\
\hline & No & 17 & 34.0 \\
\hline & Total & 50 & 100.0 \\
\hline \multirow[t]{4}{*}{16} & An off license to sell wine and beer not to be consumed on the premises. & & \\
\hline & Yes & 11 & 22.0 \\
\hline & No & 39 & 78.0 \\
\hline & Total & 50 & 100.0 \\
\hline \multirow[t]{4}{*}{17} & Anon-license to sell wine and beer which may be consumed on the premises & & \\
\hline & Yes & 24 & 48.0 \\
\hline & No & 26 & 52.0 \\
\hline & Total & 50 & 100.0 \\
\hline \multirow[t]{4}{*}{18} & $\begin{array}{l}\text { Any person who contravenes to the above statements shall be guilty of an offence and liable on summary conviction to } \\
\text { a fine. }\end{array}$ & & \\
\hline & Yes & 30 & 60.0 \\
\hline & No & 20 & 40.0 \\
\hline & Total & 50 & 100.0 \\
\hline
\end{tabular}

Source: Field survey, 2015

Tables 6 and 7 deals with alcohol regulations which are in accordance with the Liquor License Act 1970 (ACT 339). These regulations were used to test the knowledge level of the operators and averagely, about half of the respondents were totally unaware of these regulations, and so, do not observe them.

Table 8. Rules relating to minors (License Act 1964).

\begin{tabular}{lll}
\hline Statements & Frequency & Percentage \\
\hline Can a minor enter a bar & & \\
Yes & 43 & 86.0 \\
No & 7 & 14.0 \\
Total & 50 & 100.0 \\
Can a minor drink in a bar & & \\
\hline
\end{tabular}

\begin{tabular}{lll}
\hline Statements & Frequency & Percentage \\
\hline Yes & 25 & 50.0 \\
No & 25 & 50.0 \\
Total & & \\
Can a minor work in a bar & & \\
Yes & 16 & 32.0 \\
No & 34 & 68.0 \\
Total & 50 & 100.0 \\
\hline
\end{tabular}

\section{Discussions}

\subsection{Governmental Body Responsible for the Enforcement of Alcohol Laws}

There search adopted two research tools together data. An 
interview section was used to obtain information from the law regulators. From the data gathered, it was realized that the Accra Metropolitan Assembly (A.M.A) is one of the law regulatory agencies responsible for issuing license, educating and monitoring the activities of these operators from time to time to ensure the compliance of the law. The Ghana Police Service is also one of the enforcement bodies which check the activities and behavior of alcohol outlet operators and consumers both on and off premises. They do this because most consumers tend to abuse alcohol which leads to violence in the society. [14] argue that extremely large doses of alcohol, for example, lead to drowsiness, violence and increase risk of abuse; alcohol may also increase crime by providing an "excuse motive" for crime commission. The Ghana Standards Authority checks the authenticity, health benefit / risks of liquors for quality standards before they are released on to the market. The other duties of the AMA are to ensure that the operators abide by the rules and regulations governing the industries, to check bar proprietors from desisting from engaging minors to sell alcohol to the public. Likewise it is their duty to prevent minors from entering the premises to drink. The Ghana Police Service has the authority to arrest and prosecute a citizen who contravenes these regulations. Some of the regulations obtained include:

a) Not selling to minors under18years;

b) Not operating without a license;

c) Person below 18years are prohibited to take alcohol;

d) Some should not be engaged to sell alcohol in buses and offices and elsewhere.

\subsection{Summary}

This study revealed that the AMA is the law regulatory agency responsible for issuing license, educating and monitoring the activities of these operators from time to time to ensure the compliance of the law. The Ghana Police Service also serves as the enforcement body which checks the activities and behavior of alcohol outlet operators and consumers on and off premises.

The study also revealed that although the operators were aware of the negative effects of excessive alcohol intake, all that they seek are the profits they will gain when a customer wants to buy more. From the findings, it was realized that regulators are to randomly check these alcohol outlet operators to verify their level of compliance of the laws, but it seems that this is not done as often as it should be. The penalty for defaulting the regulations are fines and withdrawal of license, and persistence sometimes leads to prosecution at the court.

\section{Conclusion}

The alcohol regulations in Ghana gives a clear guideline to alcohol operators who sell alcohol, on how to sell hard liquor to the public; the age limit, the necessary requirements needed and the trading hours of these outlets.

Based on the findings, it is clear that there is a gap between the laws and what is actually being practiced. The alcohol regulations are not being enforced, operators are not observing the rules because most of the rules are not communicated to them and they are familiar with the age limit but do not observe it. Some of the law regulators based on the findings do not even know these laws and therefore do not know when to take action.

Alcohol as already indicated has tremendous negative effect both to the individual and the society at large than it positive effects therefore if proper measures are not put in place to monitor and check these operators on how they sell, to whom they sell and when they sell these liquors, then our future as a nation is fault.

\section{References}

[1] Carpenter, C., (2007). Heavy Alcohol Use and Crime: Evidence from Underage Drunk Driving Laws. Journal of Law and Economics.

[2] Chan, B. and Mackenzie M., (2013). Introduction to hospitality operations.

[3] Cook Philip (2007). Paying the Tab: The Costs and Benefits of Alcohol Control, Prince ton University Press.

[4] Dee, Thomas, (1999). State Alcohol Policies, Teen Drinking and Traffic Fatalities, Journal of Public Economics.

[5] Dordoye, E.K., (2009). The myths of alcohol use in Ghana, daily graphic.

[6] Edwards, G., Anderson, P., Babor, T., 1994). Alcohol Policy and the Public Good. New York: Oxford University Press.

[7] Freisthler, B., Grunewald P., Remer J.,(2007). Exploring the spatial dynamics of alcohol outlets and child protective services referrals, substantiations, and foster care entries.

[8] Gruenewald, Freisthler, Remer, B., LaScala, E., and Treno, A., (2006). Ecological models of alcohol outlets and violent assaults: crime potentials and geo spatial analysis.

[9] Manning, W., Keller E, Newhouse, J., Sloss, E and Wasserman, J., (1989). The taxes of sin: Dosmokers and drinkers pay their way, Journal of the American Medical Association.

[10] Popova S., Giesbrecht N., Bekmuradov, D and Patra J, (2009). Hours and Days of Sale and Density of Alcohol Outlets: Impacts on Alcohol Consumption and Damage.

[11] Cook and Moore (2001). Violence reduction through restriction on alcohol availability. Alcohol health and research world 17(2)151-171.

[12] Wagenaar and Toomey (2002) Effects of the MLDA on alcohol consumption, traffic crashes, and other health-related outcomes.

[13] Shults et al. 2001; Wechsler and Nelson (2010) inciples of Addiction: Comprehensive Addictive Behaviors and Disorders.

[14] Carpenter, J.C. and Dobkin C., (2010). The Effect of Alcohol Access on Consumption and Mortality: Regression Discontinuity Evidence from the Minimum Drinking Age. American Economic Journal. 